\title{
Experimental simulation of nitrogen and phosphorus release during marine dumping of dredged sediment
}

\author{
Wei Liu ${ }^{1, *}$, Pibo Wang ${ }^{2}$, Bin Zhou ${ }^{2}$, Qingfeng Chen ${ }^{1, *}$, Junjian $\mathrm{Ma}^{1}$, Qing $\mathrm{Li}^{1}$, and Jing Zhang ${ }^{1}$ \\ ${ }^{1}$ Qilu University of Technology (Shandong Academy of Sciences), Shandong Analysis and Test Center, 250014 Jinan, P.R. China \\ ${ }^{2}$ Shandong Provincial Key Laboratory of Marine Ecology and Environment \&Disaster Prevention and Mitigation, 266061Qingdao, P.R. \\ China \\ ${ }^{3}$ Marine Engineering Prospecting Institute of North China Sea, State Oceanic Administration, 266061Qingdao, P.R. China
}

\begin{abstract}
Marine dumping of dredged sediment results in the release of considerable amounts of nitrogen and phosphorus into the seawater. In this study, we evaluated the release pattern of nitrogen and phosphorus during sediment dumping through experimental simulation under different mixing ratios and temperatures. The concentration of $\mathrm{NO}_{3}-\mathrm{N}, \mathrm{PO}_{4}-\mathrm{P}$, and total phosphorus (TP) in seawater quickly increased in less than 1 $\mathrm{h}$ after mixing of sediment and seawater and remained stable thereafter. The concentration of $\mathrm{NH}_{4}-\mathrm{N}$ increased and peaked at $0.25 \mathrm{~h}$, but quickly decreased thereafter. The concentration of $\mathrm{NO}_{3}-\mathrm{N}_{1} \mathrm{NH}_{4}-\mathrm{N}_{2} \mathrm{PO}_{4}-$ $\mathrm{P}$, and TP in seawater showed a positive correlation with the mixing ratio. The contribution of $\mathrm{NO}_{2}-\mathrm{N}$ from sediment to water was negligible and there was no obvious difference in the release amount among different mixing ratios. The release amount of each measured nutrient at $25^{\circ} \mathrm{C}$ was marginally higher than that at $15^{\circ} \mathrm{C}$, suggesting that marine dredging and dumping should be performed in winter rather than in summer. The release amount of $\mathrm{NO}_{3}-\mathrm{N}, \mathrm{NO}_{2}-\mathrm{N}, \mathrm{NH}_{4}-\mathrm{N}, \mathrm{PO}_{4}-\mathrm{P}$, and $\mathrm{TP}$ in a 5000- $\mathrm{m}^{3}$ vessel reached 26.5, 17.6, 0.28, 1.68 , and $1.68 \mathrm{~kg}$, respectively. This study provides a detailed evaluation of nitrogen and phosphorus release pattern in marine sediment dumping process, which will be helpful for the conservation and selection of marine dumping areas.
\end{abstract}

\section{Introduction}

Dredging and dumping of dredged sediment are regular operations in harbors worldwide, especially in estuaries where sedimentation is severe ${ }^{[1]}$. The dredging and dumping practices result in the release of large amounts of sediments into the sea, significantly increasing the concentration of suspended particles in seawater and affecting marine organisms both physically and chemically ${ }^{[2-3]}$. Physically, dredged sediment might suffocate immovable benthos by burying them in sea bottom, which can lead to habitat changes as a long-term effect $^{[4]}$. Chemically, biogenic elements and contaminants including heavy metals and organic pollutants released from dredged sediment may cause serious environmental problems such as eutrophication and excessive pollution in coastal areas ${ }^{[5-6]}$.

Nitrogen and phosphorus are key biogenic elements in a water ecosystem. However, at high concentrations, they might cause severe eutrophication. Studies have showed that nitrogen and phosphorus can be released from re-suspended sediment by both natural and artificial sources ${ }^{[7-8]}$. Several studies have investigated the release of nitrogen and phosphorus via sediment resuspension in natural lakes and gulfs especially caused by natural reasons including current, wave, and bioturbation ${ }^{[9-12]}$. Marine dumping of dredged sediment is one of the most common artificial modes for sediment re-suspension. However, information on the release pattern of nitrogen and phosphorus during the marine dumping process of dredged sediment is limited.

Therefore, in the present study, the release of nitrogen and phosphorus from sediment into the seawater was experimentally simulated by re-suspending harbor sediment into the seawater from the corresponding marine dumping area, in order to provide basic information for the conservation of environment and selection of marine dumping areas.

\section{Material and method}

\subsection{Sampling}

Sediments in the natural state were sampled with a grab sampler from the Bohai Sea in Jinzhou Harbor $\left(40^{\circ}\right.$ $48^{\prime}$ N, $120^{\circ} 50^{\prime}$ E), P.R. China in February 2018 and were maintained at $4^{\circ} \mathrm{C}$ in a refrigerator before analyses. The seawater for the release experiment was collected from the ocean dumping area of Jinzhou Harbor and immediately passed through $0.45-\mu \mathrm{m}$ microfiber filters, which were pre-soaked in $1 \%$ HCL solution for $24 \mathrm{~h}$ and washed with deionized water three times. The seawater was preserved at $4^{\circ} \mathrm{C}$ before use.

\footnotetext{
*Corresponding author:11_liuwei@163.com; chensden@163.com
} 
The title is set in bold 16-point Arial, justified. The first letter of the title should be capitalised with the rest in lower case. You should leave $35 \mathrm{~mm}$ of space above the title and $6 \mathrm{~mm}$ after the title.

\subsection{Methods}

Simulation experiments were performed in lab for the release of $\mathrm{NO}_{3}-\mathrm{N}, \mathrm{NO}_{2}-\mathrm{N}, \mathrm{NH}_{4}-\mathrm{N}, \mathrm{PO}_{4}-\mathrm{P}$, and total phosphorus (TP) from sediment into the seawater under different variables.

\subsubsection{Different mixing ratios between sediment and seawater}

Sediments and seawater were mixed into a beaker at mixing ratios of 125,250 , and $500 \mathrm{~g} / \mathrm{L}$, respectively. Magnetic stirrer with a temperature-adjusting device was used to simulate the mixing process of sediment and seawater after the dumping of dredged sediment. As revealed by numerical simulation and field monitoring in several marine dumping areas, the dredged sediments would completely settle to the seafloor within a few hours $^{[8,13]}$. Thus, water samples in this study were collected after being stirred for $0.25,0.5,1,1.5,2,2.5,3$, 3.5 , and $4 \mathrm{~h}$ at a stirring rate of $200 \mathrm{rpm}$ and temperature of $25^{\circ} \mathrm{C}$.

\subsubsection{Different water temperatures}

The same experimental procedure described in section 2.2.1 was conducted for the mixing ratio of $250 \mathrm{~g} / \mathrm{L}$ at $15^{\circ} \mathrm{C}$ under the control of the temperature-adjusting magnetic stirrer.

\subsection{Analysis}

Each water sample collected during the experiment was passed through a $0.45-\mu \mathrm{m}$ cellulose acetate membrane, which was pre-soaked in 1\% HCL solution for $24 \mathrm{~h}$ and washed with deionized water for three times. $\mathrm{NO}_{3}-\mathrm{N}$, $\mathrm{NO}_{2}-\mathrm{N}, \mathrm{NH}_{4}-\mathrm{N}, \mathrm{PO}_{4}-\mathrm{P}$, and TP in water were analyzed according to the Specification for Marine Monitoring Part 4: Seawater Analysis (GB17378.4-2007, General Administration of Quality Supervision, Inspection and Quarantine of P.R. China) ${ }^{[14]}$ by spectrophotometry. Specifically, $\mathrm{NO}_{3}-\mathrm{N}$ in seawater was measured by the zinc-cadmium reduction method; $\mathrm{NO}_{2}-\mathrm{N}$ was determined by the Griess-Saltzman method. $\mathrm{NH}_{4}-\mathrm{N}$ was determined by the hypobromite oxidation method; $\mathrm{PO}_{4}-\mathrm{P}$ and TP in seawater were determined by the phosphomolybdenum blue spectrophotometric method.

\section{Results and discussion}

The results of our study elucidate how nitrogen and phosphorus are released from dredged sediment after being dumped into the seawater. The concentration of $\mathrm{NO}_{3}-\mathrm{N}, \mathrm{NH}_{4}-\mathrm{N}, \mathrm{NO}_{2}-\mathrm{N}, \mathrm{PO}_{4}-\mathrm{P}$, and $\mathrm{TP}$ in the seawater collected from an ocean dumping area in Jinzhou harbor was $0.104,0.019,0.01,0.008$, and $0.016 \mathrm{mg} / \mathrm{L}$, respectively, as analyzed before the release experiments.

\subsection{Release of nitrogen and phosphorus in different mixing ratios}

\subsubsection{Release of $\mathrm{NO}_{3}-\mathrm{N}, \mathrm{NH}_{4}-\mathrm{N}$, and $\mathrm{NO}_{2}-\mathrm{N}$}

The release pattern of $\mathrm{NO}_{3}-\mathrm{N}$ among all the three mixing ratios at $25^{\circ} \mathrm{C}$ was similar, except for a marginal difference at the beginning (Figure 1). The concentration of $\mathrm{NO}_{3}-\mathrm{N}$ in seawater quickly increased from 0.104 $\mathrm{mg} / \mathrm{L}$ to the highest concentration in approximately less than $1 \mathrm{~h}$ and remained stable thereafter. This suggests that the release of $\mathrm{NO}_{3}-\mathrm{N}$ from sediment into the seawater occurs at the beginning of dumping of dredged sediment in real world marine dumping process. The released amount of $\mathrm{NO}_{3}-\mathrm{N}$ for the mixing ratio of 500 $\mathrm{g} / \mathrm{L}$ was always the highest among the three groups at the same time point. The ratio of the highest concentration of $\mathrm{NO}_{3}-\mathrm{N}$ in the seawater for the three mixing groups was $1: 2.3: 3.6$, approximately $1: 2: 4$, which was similar to the mixing ratios of sediment and seawater.

The release pattern of $\mathrm{NH}_{4}-\mathrm{N}$ was different from that of $\mathrm{NO}_{3}-\mathrm{N}$. The concentration of $\mathrm{NH}_{4}-\mathrm{N}$ rapidly increased from $0.019 \mathrm{mg} / \mathrm{L}$ to the highest point at $0.25 \mathrm{~h}$ for all the three groups, which was considerably faster than that of $\mathrm{NO}_{3}-\mathrm{N}$. Wang et al. ${ }^{[15]}$ reported that a large amount of $\mathrm{NH}_{4}-\mathrm{N}$ in sediment was distributed in pore water. Therefore, during the process of sediment re-suspension, $\mathrm{NH}_{4}-\mathrm{N}$ could release from sediments more rapidly. Thereafter, the concentration of $\mathrm{NH}_{4}-\mathrm{N}$ gradually decreased, and this trend in the $500 \mathrm{~g} / \mathrm{L}$ group was more obvious. It suggests that a certain amount of $\mathrm{NH}_{4}-\mathrm{N}$ might escape from seawater to the air during the dumping process.

The release amount of $\mathrm{NO}_{2}-\mathrm{N}$ from sediment was relatively small as shown from the slight increase of the concentration of $\mathrm{NO}_{2}-\mathrm{N}$ in seawater. The highest concentration of $\mathrm{NO}_{2}-\mathrm{N}$ appeared at $0.25 \mathrm{~h}$, and then the concentration changed marginally till the end. There were no obvious differences in the release amount between the three groups. The slight increase of $\mathrm{NO}_{2}-\mathrm{N}$ concentration in seawater implies that the contribution of $\mathrm{NO}_{2}-\mathrm{N}$ from sediment during the dumping process was insignificant.

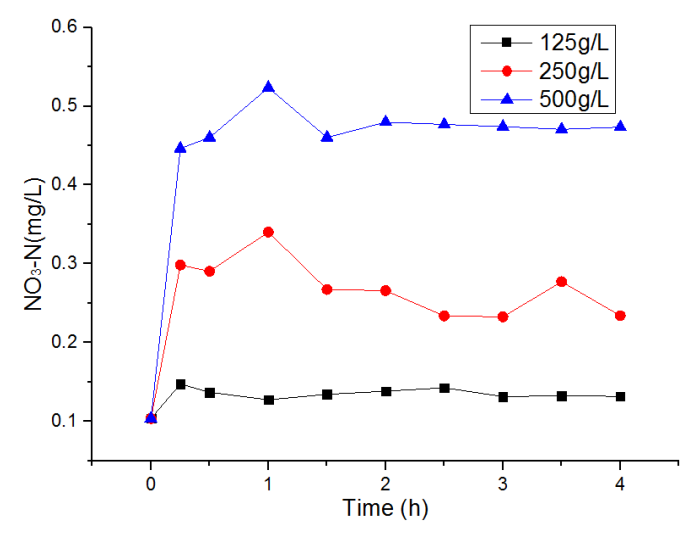



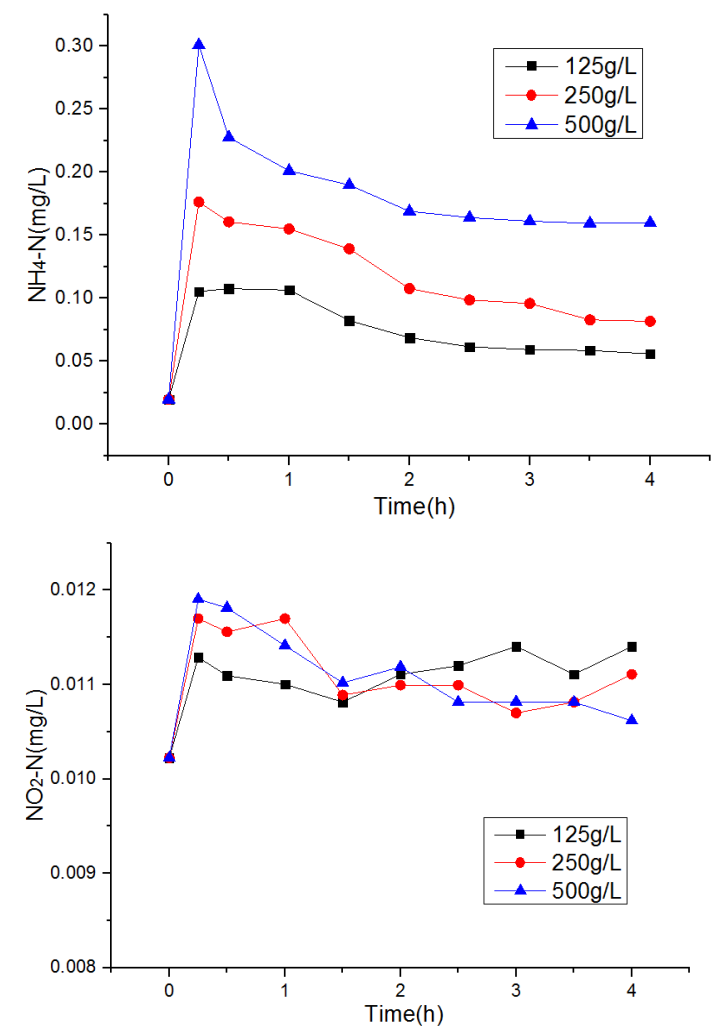

Fig. 1. Variation in the $\mathrm{NO}_{3}-\mathrm{N}, \mathrm{NH}_{4}-\mathrm{N}$, and $\mathrm{NO}_{2}-\mathrm{N}$ concentrations with time

\subsubsection{Release of $\mathrm{PO}_{4}-\mathrm{P}$, and TP}

The dynamic changes in the concentration of $\mathrm{PO}_{4}-\mathrm{P}$ and $\mathrm{TP}$ in seawater for the three mixing groups showed the same trend as that of $\mathrm{NO}_{3}-\mathrm{N}$ during the experiments. The concentration of $\mathrm{PO}_{4}-\mathrm{P}$ and TP in the seawater quickly increased in less than $1 \mathrm{~h}$ after mixing of sediment and water, and then was maintained stable. The highest concentration of $\mathrm{PO}_{4}-\mathrm{P}$ in the seawater for the three groups was $0.016,0.024$, and $0.034 \mathrm{mg} / \mathrm{L}$, respectively, while the highest concentration of $\mathrm{TP}$ in the seawater was $0.026,0.031$, and $0.047 \mathrm{mg} / \mathrm{L}$ respectively. The concentration of $\mathrm{PO}_{4}-\mathrm{P}$ and $\mathrm{TP}$ showed a positive correlation with the mixing ratios between sediment and seawater.

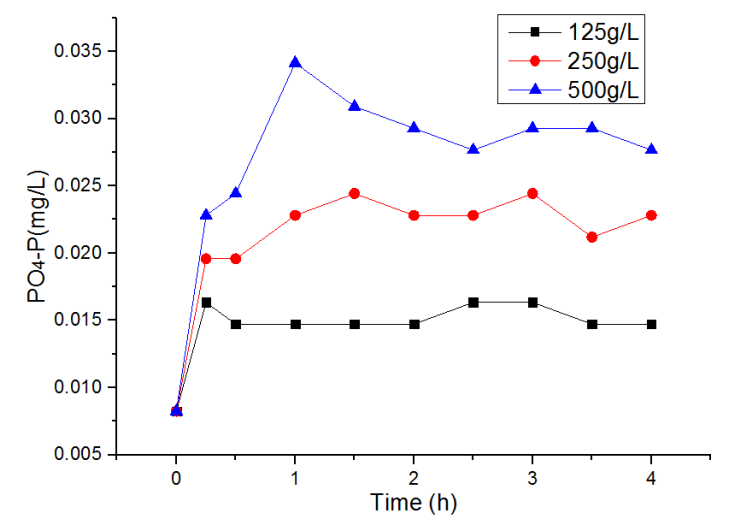

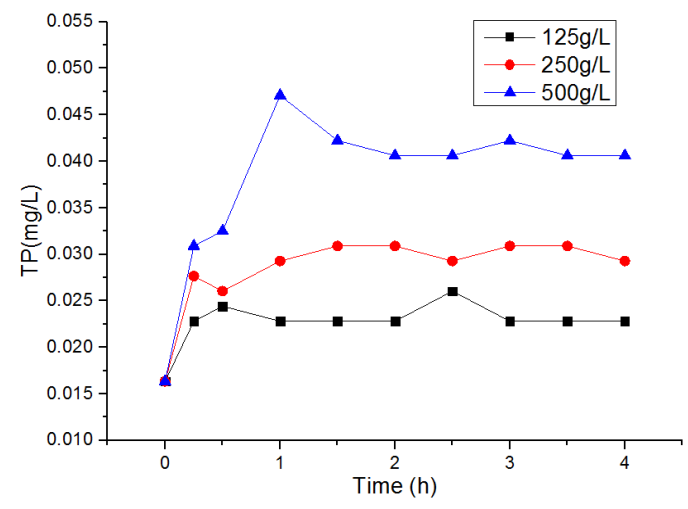

Fig. 2. Variation in the $\mathrm{PO}_{4}-\mathrm{P}$ and $\mathrm{TP}$ concentrations with time

\subsection{Release of nitrogen and phosphorus at different water temperatures}

The release experiments were conducted at $15^{\circ} \mathrm{C}$ and $25^{\circ} \mathrm{C}$ to understand the release pattern of nitrogen and phosphorus via sediment dumping in marine dumping areas in different seasons. The highest concentration of $\mathrm{NO}_{3}-\mathrm{N}, \mathrm{NO}_{2}-\mathrm{N}, \mathrm{NH}_{4}-\mathrm{N}, \mathrm{PO}_{4}-\mathrm{P}$, and $\mathrm{TP}$ in seawater during the mixing process in the $250 \mathrm{~g} / \mathrm{L}$ mixing ratio group at $15^{\circ} \mathrm{C}$ and $25^{\circ} \mathrm{C}$ has been demonstrated in Figure 3 . Although the difference between the two groups at different temperatures was not very significant, the concentration of each parameter in seawater at $25^{\circ} \mathrm{C}$ was always marginally higher than that at $15^{\circ} \mathrm{C}$. This phenomenon might be explained by the fact that nitrogen and phosphorus between the surface of sediment and water are more active at higher temperatures ${ }^{[16-17]}$. This suggests that the real word marine dredging and dumping process should be carried out in winter rather than in summer to limit the release of nitrogen and phosphorus and reduce the occurrence of eutrophication.

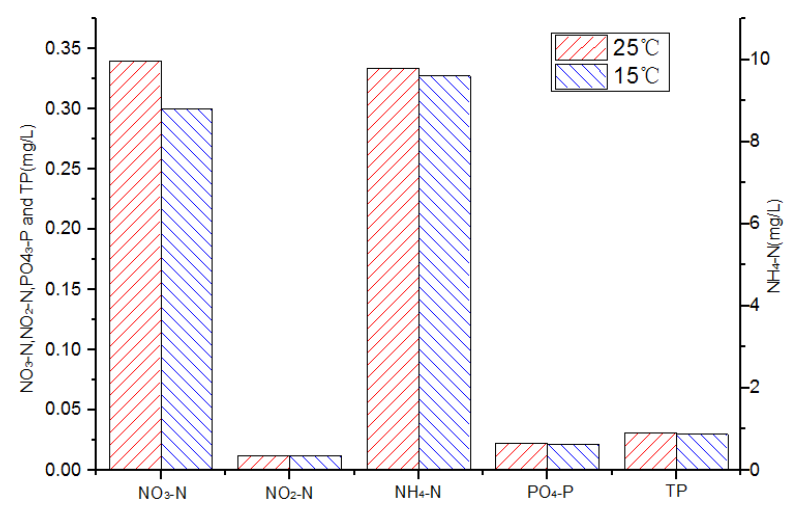

Fig. 3. Release of nitrogen and phosphorus at different water temperatures

\subsection{Release amount of nitrogen and phosphorus during the dumping process}

The group with a mixing ratio of $250 \mathrm{~g} / \mathrm{L}$ was used to estimate the amount of nitrogen and phosphorus released from sediment during the dumping process. According to the historical data of the Jinzhou Port and conventional process of dredging projects, the quantity of sediments 
carried by a single vessel is $5000 \mathrm{~m}^{3}$, of which $5 \%$ is suspended particles after sediment dumping. The proportion of mud and water in the dredged sediments is $4: 6$, and the specific gravity of suspended sediments is $2.8^{[18-19]}$. Thus, the production of suspended sediment is $280 \mathrm{t}$ for each single vessel dumping process. According to the results in sections 3.1 and 3.2, the release amount of nitrogen and phosphorus was calculated and the results are presented in Table 1. As shown in Table 1, the release amount of $\mathrm{NO}_{3}-\mathrm{N}$ was the highest, which was $26.5 \mathrm{~kg}$ for each $5000-\mathrm{m}^{3}$ vessel, followed by $\mathrm{NH}_{4}-\mathrm{N}$ which was nearly two-thirds that of $\mathrm{NO}_{3}-\mathrm{N}$. $\mathrm{PO}_{4}-\mathrm{P}$ and TP presented the same release amount of $1.68 \mathrm{~kg} / \mathrm{vessel}$ and $\mathrm{NO}_{2}-\mathrm{N}$ occupied the last position, which were all considerably less than $\mathrm{NH}_{4}-\mathrm{N}$ and $\mathrm{NO}_{3}-\mathrm{N}$.

Table 1. Release amount of nitrogen and phosphorus during the dumping process

\begin{tabular}{|c|c|c|}
\hline Nutrient factor & $\begin{array}{c}\text { Release amount } \\
\text { per unit } \\
\text { sediment }(\mathrm{g} / \mathrm{kg})\end{array}$ & $\begin{array}{c}\text { Release amount } \\
\text { from a 5000-m } \\
\text { vessel } \\
(\mathrm{kg} / \text { vessel })\end{array}$ \\
\hline $\mathrm{NO}_{3}-\mathrm{N}$ & 0.095 & 26.5 \\
\hline $\mathrm{NH}_{4}-\mathrm{N}$ & 0.063 & 17.6 \\
\hline $\mathrm{NO}_{2}-\mathrm{N}$ & 0.001 & 0.28 \\
\hline $\mathrm{PO}_{4}-\mathrm{P}$ & 0.006 & 1.68 \\
\hline $\mathrm{TP}$ & 0.006 & 1.68 \\
\hline
\end{tabular}

\section{Conclusions}

The release of $\mathrm{NO}_{3}-\mathrm{N}, \mathrm{NO}_{2}-\mathrm{N}, \mathrm{NH}_{4}-\mathrm{N}, \mathrm{PO}_{4}-\mathrm{P}$, and TP from sediment into the seawater during marine dumping showed differences. The concentration of $\mathrm{NO}_{3}-\mathrm{N}, \mathrm{PO}_{4}-\mathrm{P}$, and TP in seawater, which showed a positive correlation with the mixing ratio, quickly increased in less than $1 \mathrm{~h}$ after mixing and remained stable thereafter, whereas the concentration of $\mathrm{NH}_{4}-\mathrm{N}$ quickly increased and peaked at $0.25 \mathrm{~h}$, and then quickly decreased. The release of $\mathrm{NO}_{2}-$ $\mathrm{N}$ from sediment into water for all the mixing groups was small and similar. Marine dredging and dumping should be performed in winter rather than in summer because more nutrients were released from sediment into water at higher temperatures. For sediment dumping in a $5000-\mathrm{m}^{3}$ vessel, the release amount of $\mathrm{NO}_{3}-\mathrm{N}, \mathrm{NO}_{2}-\mathrm{N}$, $\mathrm{NH}_{4}-\mathrm{N}, \mathrm{PO}_{4}-\mathrm{P}$, and TP into water was 26.5, 17.6, 0.28, 1.68 , and $1.68 \mathrm{~kg}$ respectively. In conclusion, the release pattern of nitrogen and phosphorus presented in this study would be helpful for the selection and conservation of marine dumping areas.

\section{Acknowledgements}

This work was supported by the open research fund of Shandong Provincial Key Laboratory of Marine Ecology and Environment \& Disaster Prevention and Mitigation (No:201702); a project of the Natural Science Foundation of China (No. 41877041); and a project of Shandong Province Natural Science Foundation (No. ZR2016YL003).

\section{References}

1. O.Moog, I. Stubauer, M. Haimann, H. Habersack, P. Leitner, Hydrobiologia, 814, 109-120(2018)

2. S.G. Bolam, H.L. Rees, Environ. Manage. 32, 171188 (2003)

3. I. Donázar-Aramendía, J.E. Sánchez-Moyano, I. García-Asencio, J.M. Miró, C. Megina, J.C. GarcíaGómez, Mar. Environ. Res. 139, 64-78 (2018)

4. M. Powilleit, G. Graf, J. Kleine, R. Riethmüller, K.Stockmann, M.A.Wetzel, J.H.E. Koop, J. Marine Syst., 75, 441-451(2009)

5. A.Cesar, L.R.B. Lia, C.D.S. Pereira, A.R. Santos, F.S.Cortez, R.B. Choueri, M.R. De Orte, B.R.F. Rachid, Sci. Total Environ., 497-498, 679-687 (2014)

6. G. Choppala, E. Moon, R. Bush, N. Bolan, N. Carroll. Chemosphere, 201, 380-387 (2018)

7. L. Thomsen, G. Gerhard, V. Martens, E. Steen, Cont. Shelf Res., 14, 871-882 (1994)

8. V.K.Shukla, V.D.Konkane, T.Nagendra, J.D. Agrawal, Procedia Engineering, 116, 809-817 (2015)

9. S.L.Simpson, S.C.Apte, G.E. Batley, Environ. Sci. Technol., 32, 620-625(1998)

10. D. Paphtis, M.B. Collins, Cont. Shelf Res., 25, 2350-2365(2005)

11. G.Yahel, R.Yahel, T.Katz, Mar. Ecolo. Prog. Ser., 37, 195-2009 (2008)

12. Y.Yuan, H.Wei, L.Zhao, Cont. Shelf. Res., 28, 2630-2643 (2018)

13. S.C. Lee, K.M.Kim, H. Kim, J.W. Lee, Int'l J. Navig. Port Res., 30, 755-762 (2006)

14. General Administration of Quality Supervision, Inspection and Quarantine of the People's Republic of China, Beijing: China Standard Press, (2007)

15. Y.C. Wang, G.J. Wan, C.Q. Yin, R.G. Huang, J. Lake Sci., 14, 301-309(2002)

16. J.G.Jones, B.M. Simon, R.W. Horsley, Microbiology, 182,2823-2831(1982)

17. A. Liikanen, Biogechemistry, 59, 269-286(2002)

18. H.T. Wang, Y.H. Zhou, Y.G. Liu, Coastal Engineering, 33, 43-50(2014)

19. H.M. Xu, Mar. Environ. Sci., 19, 34-37(2000) 